FESIOE

Fundación Emilio Soldevilla para la Investigación y Desarrollo
de la Economia de la Empresa

\section{Management Letters / Cuadernos de Gestión}

\author{
journal homepage: http://www.ehu.eus/cuadernosdegestion/revista/es/
}

ISSN: 1131-6837 / e-ISSN: 1988-2157

\title{
The Technology Transfer Office (TTO): Toward a Viable Model for Universities in Morocco
}

\section{La Oficina de Transferencia de Tecnología (OTT): hacia un modelo viable para las universidades en Marruecos}

\author{
Ilham Taouaf*, Omar Elyoussoufi Attou ${ }^{\mathrm{a}}$, Said El Ganich ${ }^{\mathrm{b}}$, Moha Arouch $^{\mathrm{c}}$ \\ a PhD in Innovation Management and Technology Transfer, Engineering, Industrial Management \& Innovation Laboratory, Faculty of Sciences and Technics (FST), \\ Hassan First University of Settat, Km 3, B.P. : 577 Route de Casablanca, Morocco - om.elyoussoufi@gmail.com \\ ${ }^{b} \mathrm{PhD}$ in management sciences, Strategy and Management of Organizations Laboratory. National School of Business and Management (ENCG). Hassan First University \\ of Settat, Km 3, B.P. : 658 Route de Casablanca, Morocco - elganich@yahoo.fr \\ c Professor of higher education, Engineering, Industrial Management \& Innovation Laboratory. Faculty of Sciences and Technics (FST), Hassan First University of Settat, Km \\ 3, B.P. : 577 Route de Casablanca, Morocco - moha.arouch@uhp.ac.ma
}

* Corresponding author: PhD Student, Engineering, Industrial Management \& Innovation Laboratory. Faculty of Sciences and Technics (FST), Hassan First University of Settat. Km 3, B.P. : 577 Route de Casablanca. Morocco - i.taouaf@uhp.ac.ma - https://orcid.org/0000-0002-6617-6258

\section{A R T I C L E I N F O}

Received 11 September 2019, Accepted 16 April 2020

Available online 10 December 2020

DOI: $10.5295 /$ cdg.191179it

JEL CODES: M15, O32.

\section{A B S T R A C T}

The link between the enterprise and the university in Morocco is positioned within the framework of what is commonly known as the "University's Third-Mission". This relationship is primarily concerned with continued education, consultancy, collaborative research and development (R\&D) and technology transfer from the university to the enterprise. This third mission has been promoted by the university through the establishment of specialized structures such as university enterprise interfaces, incubators and technological information centres for invention patents. Also, several strategies and programs of incentives for innovation have been promoted by the public authorities to create a national system of innovation in Morocco. However, all these efforts failed to unleash and activate the potential of Moroccan universities. In this work, we will propose an effective and efficient institutional Technology Transfer (TT) policy backed up by a complete repository related to the establishing of the University Technology Transfer Office (UTTO). This proposal complements the work done in a previous paper, which assesses the different policies and programs within Moroccan universities, related to TT activities, and proposes a remodelling of the value chain of the process of technology transfer in the universities.

Keywords: Innovation, Technology Transfer Offices, University's Third-Mission, National Innovation System, Morocco.

\section{R E S U M E N}

El vínculo entre la empresa y la universidad en Marruecos se posiciona en el marco de lo que comúnmente se conoce como la «tercera misión de la universidad». Esta relación se refiere principalmente a la educación continua, consultoría, investigación y desarrollo colaborativo ( + D) y transferencia de tecnología de la universidad a la empresa. Esta tercera misión ha sido promovida por la universidad mediante el establecimiento de estructuras especializadas tales como interfaces empresariales universitarias, incubadoras y centros de información tecnológica para patentes de invención. Además, las autoridades públicas han promovido varias estrategias y programas de incentivos para la innovación a fin de crear un sistema nacional de innovación en Marruecos. Sin embargo, todos estos esfuerzos no lograron liberar y activar el potencial de las universidades marroquíes. En este trabajo, propondremos una política institucional eficaz y eficiente de Transferencia de Tecnología (TT) respaldada por un repositorio completo relacionado con el establecimiento de la Oficina de Transferencia de Tecnología de la Universidad (UTTO). Esta propuesta complementa el trabajo realizado en un documento anterior, que evalúa las diferentes políticas y programas dentro de las universidades marroquíes, relacionadas con las actividades de TT, y propone una remodelación de la cadena de valor del proceso de transferencia de tecnología en las universidades.

Palabras clave: Innovación, Oficinas de Transferencia de Tecnología, Tercera Misión de la Universidad, Sistema Nacional de Innovación, Marruecos. 


\section{INTRODUCTION}

The link between the enterprise and the university in Morocco is positioned within the framework of what is commonly known as the "University's Third-Mission". This relationship is primarily concerned with continued education, consultancy, collaborative research and development (R \& D) and technology transfer from the university to the enterprise.

This third mission has been promoted by the university through the establishment of specialized structures such as university enterprise interfaces, incubators and technological information centres for invention patents. Also, several strategies and programs of incentives for innovation have been promoted by the public authorities to create a national system of innovation in Morocco. All these efforts have been made since 2000 (Elyoussoufi Attou and Arouch 2016).

Indeed, the adoption of Law $\mathrm{n}^{\circ}$ 01-00 governing the functioning of Moroccan universities marked the beginning of the third mission. In particular, it widened the scope of the university (Law $\left.n^{\circ} 01-00,2000\right)$, enabling it to valorise and commercialise the results of research and the transfer of technology to companies (Etzkowitz 2003; Rasmussen et al. 2006). Therefore, beyond the traditional activities of creating and disseminating knowledge, the third mission of the university is to manage, protect and commercialise intellectual property (invention patents), promote the creation of start-ups and spin-offs, carry out collaborative R \& D projects and transfer technology to economic partners (Etzkowitz 2003; Rasmussen et al. 2006; Wright et al. 2008).

Recently, activities and structures related to the third mission have gained popularity in universities and research institutes around the world (Van Looy et al. 2011).

The Technology Transfer Office (TTO) (Ambos et al. 2008; Siegel et al. 2007; Tushman and O'Reilly 1996) is one of the most important functions created by the universities. They are autonomous units that support most of the TT activities.

The results of commercialisation, research and the missions of the TTOs have been widely discussed in the literature. They focus primarily on the following concerns:

- The role of the TTO in licensing (Siegel et al. 2003b; Thursby et al. 2001) and patenting (Coupe 2003).

- The creation and performance of university spin-offs (Link and Scott 2005; Lockett and Wright 2005; Lockett et al. 2003).

- The encouragement of researchers to disclose their inventions and the assessment of patentability, technological validity and commercial potential (Siegel et al. 2003a; Vohora et al. 2004).

- The role of the interface, which promotes solutions to the problem of asymmetrical information between industry and the university (Macho-Stadler et al. 2007) and alleviates uncertainty related to the profitability of new inventions (Hoppe and Ozdenoren 2005).

Some studies included detailed inventories of the activities and functions of the TTO (Siegel et al. 2007). As for the organization of the TTO, in addition to the classic form of unit under the central authority of the university, several other forms have been identified and analysed:
- The three archetypes identified by Markman et al. (2005) vary according to the degree of autonomy granted to the TTO (traditional university structure, non-profit foundation and a profit-making subsidiary undertaking).

-Four organizational forms proposed by Bercovitz et al. (2001): unitary structure (U-form), multi-divisional structure (M-form), holding company (H-form) and matrix structure (MX-form).

- The decentralized TTO (Debackere and Veugelers 2005).

A review of the TTO literature showed the specific context of universities in industrialised countries, especially Anglo-Saxon universities. This explains the scarcity of research focusing on the role of TTOs in the upstream phases of the Technology Transfer (TT) process that strongly influence the degree of success. In the case of Moroccan universities, the specific TT process has been identified and modelled in a previous study (Elyoussoufi Attou et al. 2019). Also, we have identified the characteristics and primary functions of the TTO in Moroccan universities that we refer to as the University Technology Transfer Office (UTTO).

At the Moroccan level, the equivalent of the TTO is the university-enterprise interface structures established since 1998 in Moroccan universities and research centres (Elyoussoufi Attou and Arouch 2016; Elyoussoufi Attou et al. 2019).

As part of our previous study (Elyoussoufi Attou et al. 2019), we were able to:

- Analyse the policies, programs, practices and achievements of Moroccan universities related to TT.

- Analyse and model the current TT process in Moroccan universities.

- Propose a value chain for the TT process more appropriate to Moroccan universities, while detailing the characteristics and main functions of the UTTO in the universities.

- Propose measures for adoption by Moroccan universities to professionalize UTTO activities.

In our current study, we will document the mission and role of UTTOs in the stages of the TT process value chain with a focus on the upstream phases. For Moroccan universities, we also propose an efficient TT institutional policy supported by a complete repository relating to the implementation of UTTOs. This repository includes setting up conditions, the attributions and activities, the components and the organizational aspect.

\section{METHODOLOGY}

To define the missions and roles of the UTTOs and develop an institutional policy for efficient TT, we proceeded through the following steps:

- Analyse the reports from the various stakeholders in the Moroccan scientific research and innovation community (MHESRET 2013; CNRST 2017; MIITDE 2017; MNEPTHESR 2017a; OMPIC 2017).

- Analyse the programs promoting innovative $\mathrm{R} \& \mathrm{D}$ for enterprises:

- Technology Diffusion Network -RDT- (2003-2011) (MHESRET 2013).

- INNOV’ACT program (2009-2012) (MHESRET 2013, 2017c). 
- Analyse the TT process and Intellectual Property (IP) management in the 8 out of 12 Moroccan universities most affected by these activities:

- Select public universities based on their valuation and technology transfer structures (MNEPTHESR 2017a).

- Organise direct interviews with current and former managers in charge of University-enterprises Interfaces.

The methodology adopted for this study is a holistic approach, which consists of the following:

- Use the results of our previous study (Elyoussoufi Attou et al. 2019) in which we proposed modelling the value chain for the TT process in Moroccan universities as the basis for an institutional policy for TT in Morocco;

-Examine the existing national and institutional TT policies and innovations based on direct interviews with:

- Managers of TT activities in the universities.

- Officials of national agencies and other bodies involved in the national TT system: The Moroccan Office of Industrial and Commercial Property (OMPIC), Ministry of Industry, Investment, Trade, and the Digital Economy (MIITDE), National Agency for the Promotion of Small and Medium Enterprises (ANPME), Ministry of Scientific Research and Innovation (MSRI) and The Moroccan National Centre for Scientific and Technical Research (CNRST).

\section{THE TTO IN MOROCCO}

\subsection{University-enterprise interfaces}

Since 1998, university-enterprise interfaces have been established in Moroccan universities (Elyoussoufi Attou and Arouch 2016) through a national support program (MNEPTHESR 2017a, 2017b). The National Program for University-Enterprise Interface Structures (NPUEI) had, as its primary motivation, the need for rapprochement between the University and the Enterprise to meet the following challenges:

- The openness of the Moroccan economy (Globalization of markets).

- Technological evolution (Knowledge Economy).

- Requirements for economic competitiveness.

- Social expectations of the Moroccan population.

- Compliance with new laws adopted between 1998 and 2000

(Law $\mathrm{n}^{\circ}$ 01-00) as the legal framework for the charter of investment, and the $\mathrm{R} \& \mathrm{D}$ provisions within the framework of the finance law (2000-2009)

This program encourages the creation, professionalization, and federation of Interfaces. These interfaces were created as structures in the university (MNEPTHESR 2017a, 2017b).

The evolution of these structures has been ongoing since 1998 when a pilot program incorporating the "University-Enterprise Interface" concept was launched. By 2011, there were 26 operational interfaces at the national level.

NPUEI (1998-2011) allowed Moroccan universities to embrace the international concept of TTO. To capitalize on the success of NPUEI, we were able to propose measures to professionalize UTTO activities (Elyoussoufi Attou et al. 2019). These measures cover all facets of the TTO issue: legal and regulatory, coordination and governance, technical coaching and financial support at the national level and measures to be taken by the university.

In addition, we will focus on the crucial role of the TTO in bridging the gap between the University-Enterprise partnership and the need for a university program (proof of concept) managed by the TTO.

\subsection{Measures to professionalize UTTO activities}

The following table summarizes the measures to be adopted and the roles to be played by the university's partners to professionalize the activities of the UTTOs. The measures take into account the context of the university and rely on the literature relating to the performance factors of the university TTOs for executing TT activities (Tornatzky and Waugaman 1999).

Table 1

Measures to operationalise and develop UTTO activities

\begin{tabular}{|c|c|}
\hline & \\
\hline & \multirow{10}{*}{$\begin{array}{l}\text { Legal and Regulatory } \\
\text { Adopt a legal framework } \\
\text { (associations, private valorisation } \\
\text { company) that offers advantages } \\
\text { such as: } \\
\text { - Financial and administrative } \\
\text { autonomy. } \\
\text { - Simplification of procedures. } \\
\text { - Strengthening good } \\
\text { governance. } \\
\text { - Encouragement of researchers. } \\
\text { - Effective involvement of the } \\
\text { private sector in the UTTO's } \\
\text { decision-making body. } \\
\text { Pending the determination of } \\
\text { legal status: } \\
\text { - Formalize the status of the } \\
\text { UTTO within the university. } \\
\text { - Formally identify the missions } \\
\text { of the UTTOs. } \\
\text { - Mobilise sufficient human } \\
\text { and financial resources in line } \\
\text { with the expected objectives } \\
\text { (Expertise, IP Management, } \\
\text { proof of concept activities, etc.). } \\
\text { - Ensure that researchers } \\
\text { have access to the financial } \\
\text { performance of completed } \\
\text { projects. } \\
\text { - Develop a culture conducive to } \\
\text { TT activities in the university. } \\
\text { - Professionalise the TTO structure } \\
\text { (business oriented TTO). } \\
\text { - Adopt well-defined policies, } \\
\text { rules, and procedures. } \\
\text { - Adopt an approach for long- } \\
\text { term tangible results. }\end{array}$} \\
\hline & \\
\hline $\begin{array}{l}\text { Estal } \\
\text { mecl } \\
\text { finar }\end{array}$ & \\
\hline & \\
\hline Coordination and Governance & \\
\hline $\begin{array}{l}\text { ations } \\
\text { upport. } \\
\text { to }\end{array}$ & \\
\hline $\begin{array}{l}\text { Role } \\
-\mathrm{Pa} \\
\text { eff }\end{array}$ & \\
\hline & \\
\hline $\begin{array}{l}\text { - Work directly on R\&I } \\
\text { innovation projects } \mathrm{W} \\
\text { laboratories and resea }\end{array}$ & \\
\hline & \\
\hline
\end{tabular}

Source: Own elaboration. 


\subsection{Promoting technology transfer from the perspective of a public university: roles of the TTO}

TTOs often experience a delicate balance between actors with opposing interests. For example, in the U-E interface that is typical of a Moroccan university, the stakeholders include:

- Professors-researchers, administrative staff, and students.

- Licensees, industry sponsors, and investors.

- Public funders, administrations, and the general public.

A successful TTO must find common ground where the interests of all its stakeholders are represented. This requires a great deal of effort to encourage collaboration.

\section{A. UNIVERSITY-ENTERPRISE PARTNERSHIPS}

The primary indicators of TTO performance are patents, licenses and royalties. However, other means of developing upstream of TT activities should not be neglected, particularly those pertaining to university-enterprise collaboration through expertise and consultation.

Although there is a significant variety of TTOs in relation to the services offered, it is also generally accepted that the two primary ways to transfer technology are by licensing the technology to companies or creating new companies (the so-called university spin-off companies or USOs). Statistics collected by Bray and Lee (2000) showed that the income from university spin-offs is several times higher than the annual income from conventional licenses.

However, several spin-off initiatives by Moroccan universities have been confronted with the difficulties in getting final authorization from the Ministry of Finance due to poor coordination between the two ministries to implement Law $\mathrm{n}^{\circ} 01$ 00. Simplifying the final authorization process is a necessity to encourage the development of Moroccan spin-off companies. (Elyoussoufi Attou et al. 2019)

The role of the TTO is to facilitate industry-sponsored research. Successful collaborations often start with personalized relationships with university researchers who share a common scientific interest with their counterparts in a developing enterprise. In addition, the TTO and the university must create a favourable environment in which to foster and strengthen these relationships for a sustainable collaboration.

The challenge for TT managers is to conduct well-documented readiness and technological risk assessments at key points in the program life cycle. Technological Maturity Levels (TRL) is a systematic process for assessing the maturity of a particular technology. It also compares the level of maturity between different types of technology (Mankins 1995).

The TRL was developed between 1970 and 1980 by the National Aeronautics and Space Administration (NASA) and which guaranteed a more effective assessment of the maturity of new technologies and more effective in this regard (Mankins 2009). Since then, TRLs have been adopted by the General Accountability Office (GAO) of the United States Congress, adopted by the United States Department of Défense (DOD), and are being considered for use by many other organizations. Overall, TRLs have proven to be very effective in communicating the state of new technologies within often diverse organizations (Mankins 2009). The TRL scale has largely contributed to the discipline of assessing technological readiness. And, scale is likely to continue to play an increasingly important role in the future of technology and systems management. As systems become increasingly dependent on the simultaneous development of multiple technologies, the use of TRL is more widespread (Mankins 1995).

University research rarely exceeds Level 4 of the TRL. However, national funding mechanisms aimed at innovation in universities focus on levels 0 to 3 . This confirms the high-risk nature of projects that often require several years to achieve a marketable product or service.

However, this university research may be attractive for companies that are looking for strategic positioning themselves with new products or ground-breaking technologies. In particular, this affects big companies that have the resources to commit to the early stages of research and development.

As for the Small and Medium-sized Enterprises (SME)/ the Small and Medium-sized Industries (SMI), the university, through the TTO, can promote the expertise and skills of university researchers to solve problems facing technology start-ups and provide them with the support they need for technological upgrading.

Promoting industry-sponsored research achieves several goals:

- Enables the company to take advantage of the university experience, expertise and infrastructure to pursue research interests consistent with its long-term vision.

- Allows the university to offer access to researchers that goes beyond basic research and directs them to applications that can find a place in the market.

This collaborative research combines the expertise of both parties. Industry researchers and engineers can partner in future research and guide academic researchers to better understand how their work will be applied in real life conditions.

A TTO can facilitate collaboration and proactively involves industry partners upstream of the TT value chain by identifying projects of interest to industry and researchers. This collaboration can build a solid footing for licensing and patent assignment downstream of the TT value chain.

\section{B. Role OF THE TTO: BRIDGING THE GAP IN THE UNIVERSITY- ENTERPRISE PARTNERSHIP}

Scientific research is similar to a high-risk company that has the potential for significant profitability. Research projects are at an early stage of development with respect to market access, while focusing on potential breakthrough discoveries.

The analysis of programs, innovation support mechanisms, and activities related to TT in Moroccan universities shows the weakness of collaborative projects with economic partners and technology services provided by universities (Elyoussoufi Attou and Arouch 2016; Elyoussoufi Attou et al. 2019).

When applying the TRL scale, we can see the gap between the point where the public funding of research ends and industry and private investors are willing to partner with the university (Usually from TRL 6 or TRL 7 levels). 


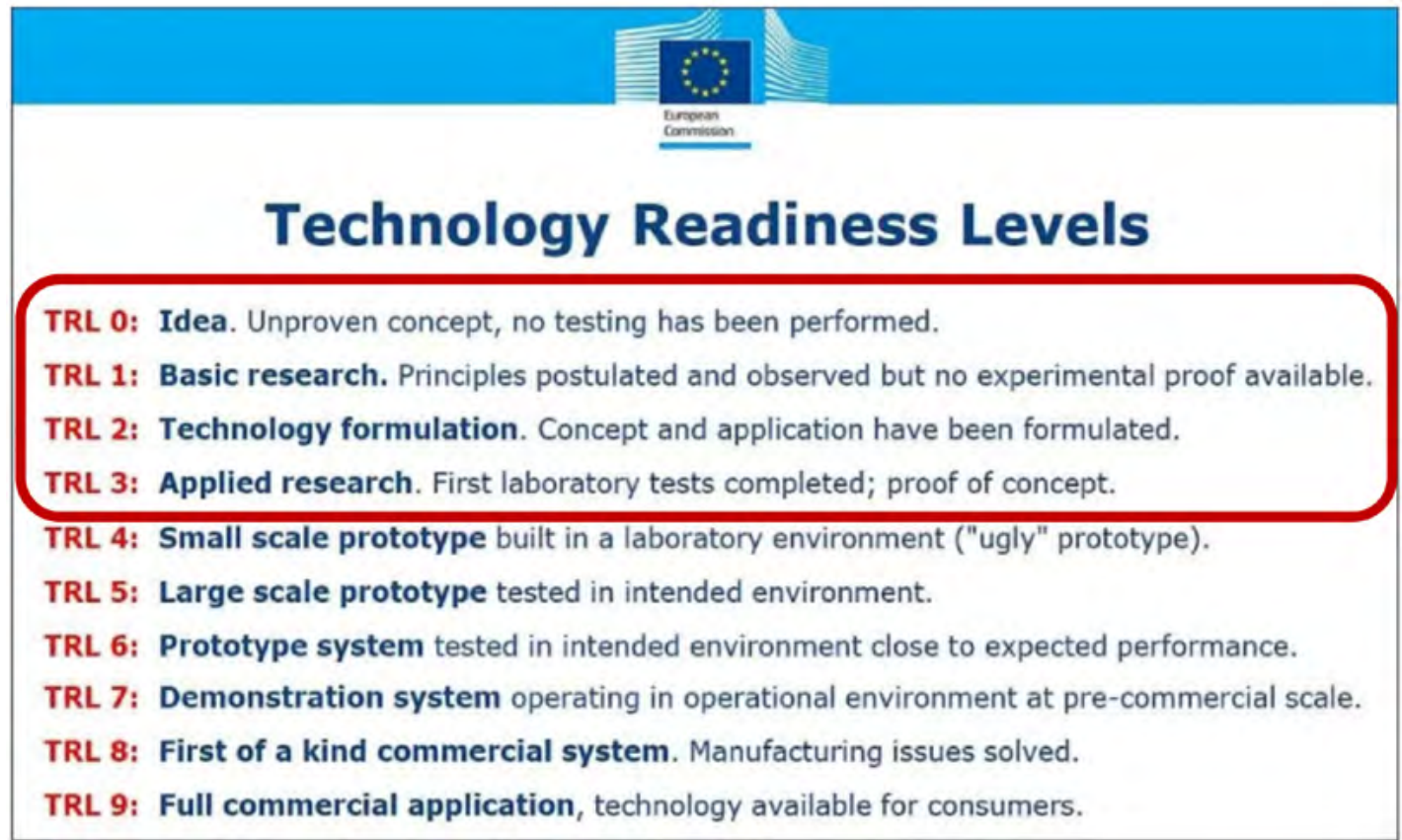

Figure 1

The Technology Readiness Levels (TRL) and coverage of public funding mechanisms in Moroccan universities from TRL 0 to TRL 3 Source: E.C. (2013).

Researchers must demonstrate a certain level of feasibility before seeking a venture partner willing to accept the risk of investment in early-stage technology. In Morocco, there is still no estimate of the budget needed to produce a "proof of concept" sufficient to exploit the potential of a technology or product under development. This important step in the TT process reduces the risk to an interested company. At present, however, very little funding is dedicated to "proof of concept" in Morocco. One exception is some small projects for university prototyping centres oriented primarily toward education and training established by OMPIC (2017) in Casablanca (Morocco).

The opportunity remains for allocating a budget and implementing a grant program within the university under the responsibility of the TTO to bridge the gap between research and commercialisation through "proof of concept".

C. Role OF THE TTO: "PROOF OF CONCEPT" PROGRAM IN THE UNIVERSITY

Such a program should benefit projects with a clearly defined obstacle between research and commercialization and make it easy to achieve the following goals:

- Accelerate both the commercialization of technologies developed in the university's research laboratories and the university IP portfolio.

- Ensure better visibility and attractiveness of the technologies either for licensing or development of start-ups.

- Attract investment and participate in job creation.

- Stimulate the local and national technology-based economy.
To evaluate proposals on their technical value and commercial potential, a certain number of directives must be respected:

- The IP must be disclosed to the TTO and must be owned by the university.

- The technology must be free from any license agreement, sponsored research or investment partners.

- To be supported, projects must include either prototype for development, commercial feasibility studies or studies to overcome a specific obstacle identified by industry.

- Requests for assistance should describe a precise and clear roadmap for business development, the market potential of the technology and how the requested support would reduce any impediments to marketing.

\section{PROPOSED STANDARDS FOR ESTABLISHING A UNIVERSITY STRUCTURE RESPONSIBLE FOR THE TRANSFER OF UTTO TECHNOLOGY}

Most universities, research institutes, and institutions not affiliated with universities have units to manage relations with economic partners. These units are called "university-enterprise interfaces". Their mission is to promote scientific research through collaboration between universities and businesses and the transfer of technology to the social and economic fabric.

These structures have staff (teacher-researchers, researchers, and administrative staff) that link the university with the enterprise and provide all the skills, know-how and technologies to solve the technical and technological problems facing the companies. 
Until now, there has been a network that links these interface structures but provides only basic coordination. The existence of a body in charge of TT within the university is an important prerequisite for any technology transfer from the university to an enterprise.

In the following sections, we propose a scaling reference for UTTOs that takes into account the different levels of maturity that characterize the TT activities and the units that ensure them in Moroccan universities. This scaling reference contains:

-A mission statement and objectives for the UTTO.

- Assignments, services, and roles provided by the UTTO.

- Conditions and operating standards of the UTTO.

- Components and organisational chart of the UTTO.

\subsection{UTTO mission statement and objectives}

The UTTO has two primary objectives. Those general objectives are further broken down into specific objectives that consider the level of initial investment and the different levels of maturity that characterize technology transfer activities in a given university.

1) Create an appropriate and efficient space that allows the articulation of supply and demand for R \& D activities. On the one hand, the university presents its offer of technology and know-how that promotes the competitiveness of enterprises and increasing the level of added value in their production. In response, the company provides additional financial resources to the university and contributes to research to be harnessed to the economy. This space allows the UTTO to:

- Value the university offer that is linked to:

- Qualified and experienced human resources (researchers and students).

- Quality research and scientific expertise at regional and national levels.

- Research laboratories covering high priority areas at the regional and national levels.

- Meet the needs of enterprises and the economic fabric of the region. This fabric is currently characterized by:

- The absence of research and development units in the companies.

- The need to achieve effective results and move as quickly as possible to the production stage.

2) Create an interactive platform that promotes technology transfer, completes the missing links in the innovation value chain, and achieves the following results:

- Launch the process of technological innovation by stimulating the transfer of skills and knowledge between the university and the enterprise. In turn, this will facilitate the development of new products and services as well as the initiation of innovative projects.

- Attract investors by improving the visibility of the university's technological offer locally, regionally and internationally.

- Facilitate the transfer of technology between the university and the enterprise by overcoming various obstacles.

- Enable and energise the innovation value chain by benefiting enterprises and researchers who will see their research activities valued and rewarded.
- Stimulate the creation of high value-added jobs for university graduates.

- Reposition the university as an important player in the socio-economic fabric of the region.

- Improve the competitiveness of local and regional enterprises.

- Perpetuate and diversify the sources of funding for R \& D activities.

- Help to identify regional and national research priorities.

\subsection{UTTO responsibilities, services and roles}

The expected services and roles of the UTTO are embodied in:

- Its mission statement and objectives.

- The different phases and stages of the TT process in Moroccan universities. The UTTO will be responsible for ensuring the activities and related services. Technology transfer in the academic context is a complex and repetitive process that involves overlapping steps and phases to form a "value chain". We will use our proposed value chain to model the TT process in Moroccan universities to develop an institutional technology transfer policy in Morocco.

- The measures taken to activate and professionalize its functions and to overcome the constraints that hinder achievement of the objectives for university technology transfer.

In addition, it is necessary to explore the different axes of economic development on which the UTTO can work. Those axes are summarized as follows:

- Providing the university with a source of revenue from commercialising the results of scientific research through:

- Establishing research partnerships with public and private customers.

- Innovation management through services provided by technology testing and analysis platforms and design and prototype centres.

- Stimulating the demand for services offered by the platforms and the design and prototyping centres that are coming out of the university. In turn, they will enhance the capacity and scientific and technical potential by using a proactive approach to the systematic research of economic partners. Hence, the need to have within the UTTO a unit responsible for communication and marketing.

- Establishing innovative incubator projects whose objective is to fund and secure contributions to promising technological projects. This should be developed with a minimum number of participating companies for a fixed period to ensure a stable income that achieves financial balance.

- Providing the university with a stable source of income by creating additional business activities such as:

- An innovative business incubator offering pre-incubation, incubation, and post-incubation services. The objective is to fund and secure stakes in promising technology companies. It should be developed in such a way that a minimum number of enterprises are hosted for a fixed period to ensure a stable income. 
- Training services specifically designed to meet the needs of local and regional economic partners.

- Services similar to those provided by the technical centres such as issuing certificates of conformity for the products of export and import companies. This means that the UTTO must secure the necessary accreditations from the relevant authorities.

- Finding other potential sources of income, which might include:

- Professional management of relations with sponsors and sources of subsidies, donations, and legacies at the national and international levels (international organizations, national enterprises, etc.).

- Active participation in international networks of research centres, incubators, etc.

- Establishment of strategic partnerships with potential investors, "business angels", venture capital companies and banks.

Based on the objectives and activities outlined above, we have summarized the services and roles expected of the UTTO in Figure 2. Services and responsibilities are organized according to the different stages of the proposed value chain we will use to model the process of technology transfer at the university.

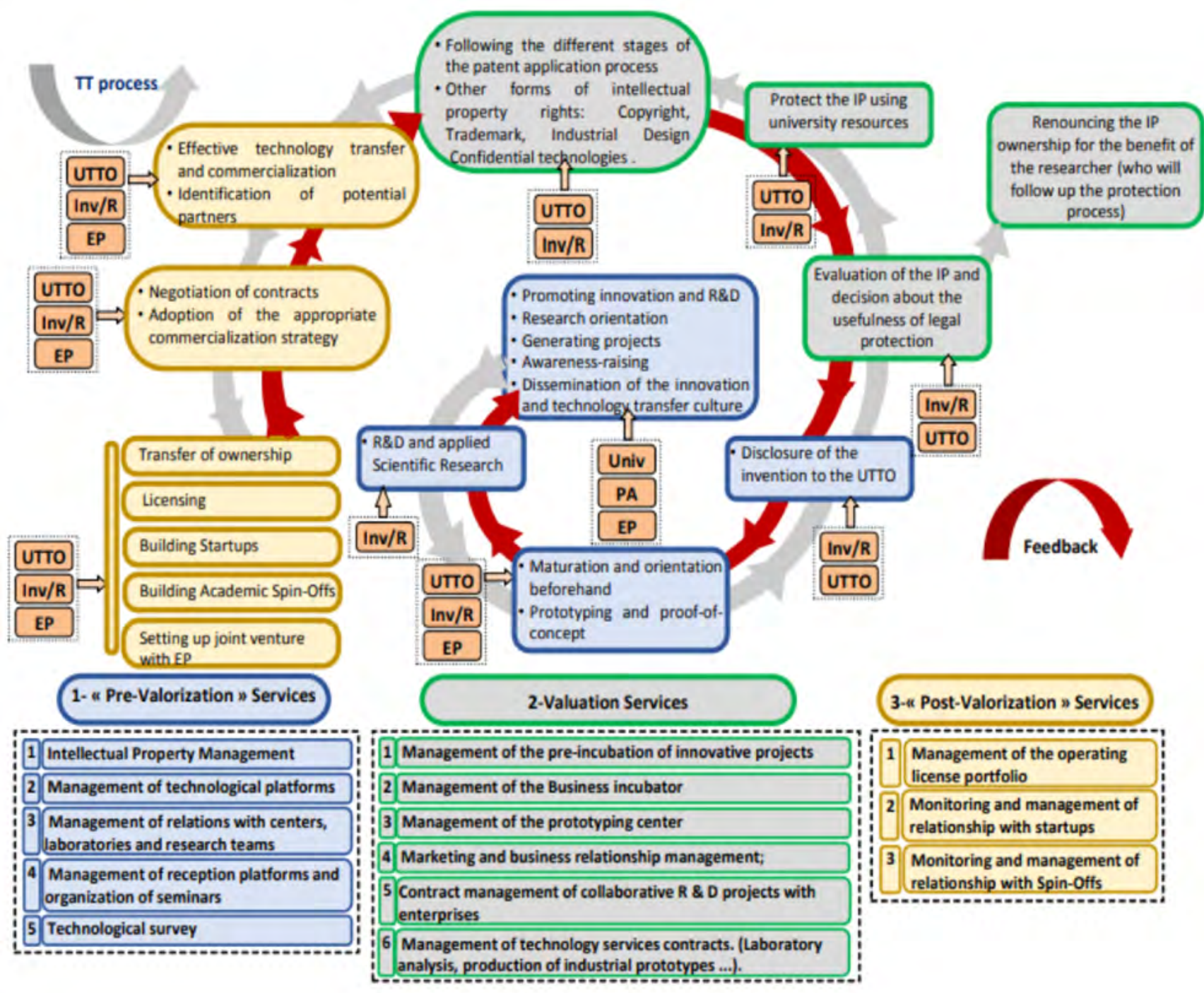

Figure 2

Services and roles expected of the UTTO in the different stages of the proposed technology transfer value chain within the University Source: Own elaboration based on our previous work: Elyoussoufi Attou et al. (2019).

Legend: Figure 2

UTTO: University Technology Transfer Office In/Res: Inventor/Researcher

EP: Economic Partners

Univ.: University
PA: Public Authorities

IP: Intellectual Property

TT: Technology Transfer 


\subsection{UTTO operating standards}

To achieve its objectives and assume the roles defined in its mission statement, the UTTO must be established at each university. In so doing, it must comply with the following standards:

1) Ensure that the objectives and activities of the UTTO are consistent with the vision, intellectual property policy, and priorities for scientific research and technological development at the university.

2) Prepare detailed procedures under which the UTTO which will resolve potential disputes that may arise between the university's stakeholders: staff (including officials), relevant ministries, the University Council, students, public and private partners, local and regional authorities, trade unions, competing universities and civil society.

3) Ensure that infrastructure planning managed by the UTTO is consistent with the adopted development strategy. The strategy must consider the future direction of the local and national economy.

4) Provide appropriate space for the reception and/or daily operation of the companies and/or their teams collaborating on research and development projects in partnership with researchers.

5) To develop cooperative networks between the enterprises and university research centres, provide a range of services and facilities to meet the needs of target enterprises.

6) Create the initial conditions to ensure a successful project. This includes a significant initial investment, quality mobilized skills and quality equipment necessary to demonstrate its commitment, professionalism and credibility to the university and its economic partners.

7) Manage effectively and efficiently the various operational activities related to technology transfer (those responsible for operational management must be highly qualified experts in their fields).

8) Adopt detailed and transparent procedures for managing technology transfer.

\subsection{UTTO Management Components}

The ability of a university to comply with the standards outlined in section 4.3 will significantly affect the organizational structure of the UTTO. We have developed two contrasting management scenarios characterized first by a minimum (or cautious) commitment to a maximum level of commitment by the university. Each university can adopt the approach most suited to its vision for the UTTO, going from the minimum scenario to the maximum scenario:

\section{A. The MiNIMUM SCENARIO}

The basic version is characterized by caution considering the reluctance of potential economic partners. This scenario is characterized by the following:

1) Limited technical infrastructure in the form of offices, a reception service and communication equipment. University facilities such as training rooms and conference rooms are requested and used when needed.

2) Use of existing university laboratories without establishing a specialized technological infrastructure designed for specific industrial or technological sectors.

3) No spaces reserved for the reception and operation of enterprises.

4) The UTTO is responsible for managing a university incubator for innovative enterprises intended exclusively for researchers and students. Or, where applicable, for coordinating with the incubator management if it is an independent unit within the university.

5) The UTTO is responsible for managing a centre on patent information at the university.

6) Common support, accompaniment, and advisory services limited to supporting researchers in their commercialisation activities.

\section{B. The MAXimum SCEnario}

The UTTO takes the form of a complex for valorisation and innovation within the university (developed version). This scenario is characterized by the following:

1) From the outset, significant initial investment and a substantial financial contribution from institutional and private donors and certain companies.

2) A strong mobilization of human resources and talents within the university to manage technological platforms.

3) Recruitment of contract human resources that are experienced in areas related to the management of technology enterprises, intellectual property and research and development projects.

4) General technical infrastructure:

- Located near the city centre and attached to the university presidency.

- Having general facilities and equipment (training rooms, conference and meeting rooms, communication infrastructure and reception service).

5) Specialized technological infrastructure targeting specific industrial or technological sectors:

- Certified testing and analysis platforms (depending on the technologies selected as a priority). These must be the most sophisticated to attract the best companies.

- Prototyping platforms.

6) Suitable spaces for the reception and/or domiciliation of enterprises or their teams collaborating on research and development projects in partnership with researchers.

7) An academic incubator for innovative enterprises.

8) A university unit in charge of intellectual property management (UUIP).

9) A unit responsible for communication and marketing. 
10) Common support, coaching and consulting services; this will be responsible for contractual services, follow-up of collaborative projects and management of technologies developed at the university.

\subsection{UTTO organizational structure}

The proposed organization chart takes into consideration the specifications, the initial conditions, and the attributions of the UTTO presented in Section 4.3. In the following, we will detail the three major poles of the UTTO and the tasks associated with them:

\section{A. Top Management}

This group is responsible for overall coordination of the structure's work. It oversees the following tasks and duties:

- Management of administrative and general affairs (administration of the site and the general technical infrastructure).

- Reception and secretarial and service.

- Human resources management (recruitment, training and career management).

-Financial management: accounting, budgeting, diversification and intensification of funding sources and monitoring and management of relationships with start-ups and spin-offs.

- Promotion of UTTO services, communication, marketing and development of relations with companies:

- Promotion of scientific and technological services provided by the university.

- Development of media used for information and communication.

- Organization of events, seminars and awareness and information campaigns.

\section{B. Research and Development}

This division is oriented primarily toward the university and has a thorough knowledge of its research work, its skills, and its scientific and technological expertise. It oversees the following duties:

- Management of relations with the research centres, laboratories and research teams of the university.

- Management of the prototyping centre.

- Management of specialized technology platforms targeting priority industrial or technological sectors of the university:

- Conducting tests and analyses and executing technology service contracts.

- Maintenance of machines and appliances.

\section{Valuation and Intellectual Property (IP)}

This pole is oriented primarily toward the companies and the socio-economic environment. It oversees the following duties:

- Management of the university incubator for innovative projects. - Management of continuous training.

- Management of intellectual property and the portfolio of operating licenses.
- Management of collaborative R\&D projects:

- Supporting the disclosure of inventions and legal protection.

- Supporting the development of innovative start-up and spinoff projects as well as R\&D projects of university researchers.

- Managing technology service contracts (Testing and analysis of platforms, production of industrial prototypes, etc.).

- Ensuring a technological watch.

\subsection{Proposed UTTO organizational structure}

The proposed organizational chart sets a flexible reference framework (Figure 3). Which allows each university to make the choice according to the initial conditions it has managed to meet for its project of setting up the "UTTO".

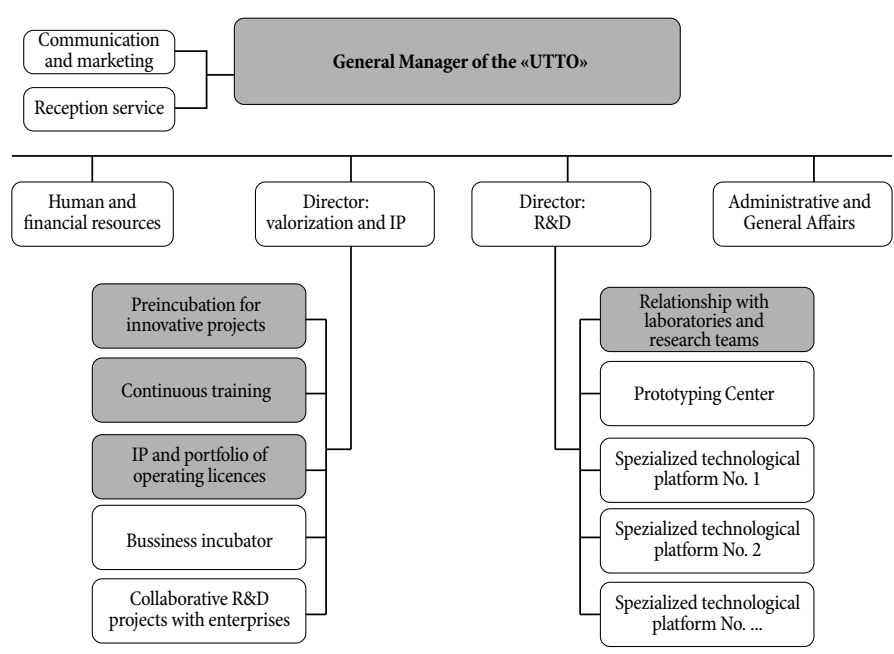

Figure 3

Proposed organization of the UTTO in its developed form (white and grey) and its basic form (grey only)

Source: Own elaboration.

Legend: Figure 3

IP : Intellectual Property

R\&D : Research and Development

\section{CONCLUSIONS}

The investments and efforts made to date have not yielded results that could materialize the economic role of the university targeted by the third mission. However, on one side, the public authorities that oversee higher education and scientific research and, on the other side, the universities have for 20 years continued to invest in developing new strategies, creating administrative bodies, mobilising human resources and promoting the means of funding.

The role, attitude, and motivation of the top university management are key parameters for the success of activities related to the university's third mission. Our study involved two complementary paths of research. First was a model of the technology transfer value chain, which examines the TT activities in Mo- 
roccan universities. In the second study, we proposed an effective and efficient institutional TT policy backed by a complete reference framework for the implementation of the University Technology Transfer Office (UTTO).

Awareness by public authorities of the importance of promoting innovation to integrate Morocco into the knowledge economy and ensure a high level of competitiveness has resulted in gradual work since 1998. Our previous study highlighted and analysed the mechanisms for promoting innovation in Morocco and identified three components: creation of innovative business, development of research results and innovative activity within the company (Elyoussoufi Attou, and Moha 2016).

The essential factors that characterize the current state of innovation in the country focus on the economic and cultural environments. Several additional factors interact in complex ways to further innovation. For example, policies and strategies have been developed and adopted, mechanisms and structures copied or designed, and financial and human resources allocated. All these were implemented and managed take account of the unique characteristics of the country as well as international standards. However, the pace of development has failed to exploit the latent potential of Moroccan universities. Nevertheless, the success of the university in the third mission remains closely connected to the developing system of innovation at the regional and national levels. Indeed, the university is increasingly considered to be the anchoring institution in its community, representing the first port of call for individuals, companies and organizations (public and private) with a variety of commercial and research innovations (Rubens et al. 2017).

According to Lockett et al. (2005), the success of universities in fostering a spinoff's success is based on greater expertise (in addition to the TTO) and more developed networks with both external organizations and individuals with access to critical resources and financing. The success of the university in its third mission greatly depends on the strategy adopted by the public authorities to encourage innovation and the exploitation of research results and the subsequent transfer of technology. This success also depends on the legal capacity put in place to emancipate universities to take on the risk. This means that, in Morocco, it will be necessary to develop a regional and national framework conducive to innovation and technology transfer.

The analysis and modelling of the so-called National Innovation System in Morocco (NIS) and all of the parameters that interact in complex ways to form the NIS will be examined in depth in subsequent studies.

\section{REFERENCES}

Ambos, T. C, Makela, K., Birkinshaw, J. and D’ Este, P., 2008. When does university research get commercialized? Creating ambidexterity in research institutions. Journal of Management Studies, 45(8), 142414. DOI: $10.1111 / j .1467-6486.2008 .00804 . x$

Bercovitz, J., Feldman, M., Feller, I. and Burton, R., 2001. Organizational structure as a determinant of academic patent and licensing behavior: An exploratory study of Duke, Johns Hopkins, and Pennsylvania State universities. Journal of Technology Transfer, 26(1), 21-35. DOI : 10.1023/A:1007828026904
Bray, M. J. and Lee, J. N., 2000. University revenues from technology transfer: Licensing fees vs. equity positions. Journal of Business Venturing, 15, 385-392. DOI: 10.1016/S0883-9026(98)00034-2

CNRST (The Moroccan National Centre for Scientific and Technical Research), 2017. Annual Report 2015. CNRST, Morocco.

Coupe, T., 2003. Science is golden: Academic R\&D and university patents. Journal of Technology Transfer, 28(1), 31-46. DOI: 10.1023/A:1021626702728

Debackere, K. and Veugelers, R., 2005. The role of academic technology transfer organizations in improving industry science links. Research Policy, 34(3), 321-342. DOI: 10.1016/j.respol.2004.12.003

E.C. (European Commission), 2013. Horizon 2020 European Commission Internet portal. Available from: https://ec.europa.eu/programmes/horizon2020/

Elyoussoufi Attou, O. and Arouch, M., 2016. Current situation of the national system of the technological innovation in Morocco. International Journal of Innovation and Scientific Research, 20 (1), 83-89. Available from: www.ijisr.issr-journals.org/abstract.php?article=IJISR-15-278-03

Elyoussoufi Attou, O., El Ganich, S., Taouaf, I., Arouch, M. and Oulhadj, B., 2019. Modelization of the value chain for effective technology transfer within universities in Morocco. International Journal of Advanced Trends in Computer Science and Engineering, 8(5), 18081823. DOI: $10.30534 /$ ijatcse/2019/03852019

Etzkowitz, H., 2003. Research groups as 'quasi-firms': The invention of the entrepreneurial university. Research Policy, 32(1), 109-121. DOI: 10.1016/S0048-7333(02)00009-4

Hoppe, H. C. and Ozdenoren, E., 2005. Intermediation in innovation. International Journal of Industrial Organization, 23(5-6), 483-50. DOI: $10.1016 /$ j.ijindorg.2005.03.003

Law $\mathrm{n}^{\circ}$ 01-00 on the organization of higher education in Morocco, 2000. O. B. No. 4800 of 1 June 2000. Dahir n $1-00-199$ of 15 Safar 1421. Available from: https://www.enssup.gov.ma/sites/default/files/ETABLISSEMENT-SUP/Dahir_n-1-00-199_du19mai2000.pdf

Link, A. N. and Scott, J. T., 2005. Opening the ivory tower's door: An analysis of the determinants of the formation of US university spinoff companies. Research Policy, 34(7), 1106-1112. DOI: 10.1016/j. respol.2005.05.015

Lockett, A., Wright, M. and Franklin, S., 2003. Technology transfer and universities' spin-out strategies. Small Business Economics, 20(2), 185-200. DOI: 10.1023/A:1022220216972

Lockett, A., Siegel, D., Wright, M., and Ensley, M. D., 2005. The creation of spin-off firms at public research institutions: Managerial and policy implications. Research Policy, 34(7), 981-993. DOI:10.1016/j. respol.2005.05.010

Lockett, A. and Wright, M., 2005. Resources, capabilities, risk capital and the creation of university spin-out companies. Research Policy, 34(7), 1043-105. DOI: 10.1016/j.respol.2005.05.006

Macho-Stadler, I., Perez-Castrillo, D. and Veugelers, R., 2007. Licensing of university inventions: The role of a technology transfer office. International Journal of Industrial Organization, 25(3), 483-510. DOI: 10.1016/j.ijindorg.2006.06.001

Mankins, J.C., 1995. Technology readiness levels. A White Paper, NASA, Washington, DC.

Mankins, J.C., 2009. Technology readiness assessments: A retrospective. Acta Astronaut, 65, 1216 - 1223, Pergamon. DOI: 10.1016/j.actaastro.2009.03.058

Markman, G. D., Gianiodis, P. T., Phan, P. H. and Balkin, D. B., 2005. Innovation speed: Transferring university technology to market. Research Policy, 34(1), 1058-1075. DOI: 10.1016/j.respol.2005.05.007

MHESRET (Ministry of Higher Education, Scientific Research and Executive Training), 2013. Annual Report 2013, MHESRET, Morocco. 
MIITDE (Ministry of Industry, Investment, Trade and the Digital Economy), 2017. Annual Report 2015. MIITDE, Morocco.

MNEPTHESR (Ministry of National Education, Professional Training, Higher Education and Scientific Research), 2017a. Annual Report 2016. MNEPTHESR, Morocco

MNEPTHESR (Ministry of National Education, Professional Training, Higher Education and Scientific Research), 2017b. University-Enterprise Partnership: National Program of University-Enterprise Interfaces. MNEPTHESR, Morocco.

MNEPTHESR (Ministry of National Education, Professional Training, Higher Education and Scientific Research), 2017c. Funding Programs for Research Projects: INNOV'ACT Program. MNEPTHESR, Morocco.

OMPIC (The Moroccan Office of Industrial and Commercial Property), 2017. Annual Report 2016. OMPIC, Morocco.

Rasmussen, E., Moen, O. and Gulbrandsen, M., 2006. Initiatives to promote commercialization of university knowledge. Technovation, 26(4), 518-533. DOI: 10.1016/j.technovation.2004.11.005

Rubens, A., Spigarelli, F., Cavicchi, A. and Rinaldi, C., 2017. Universities' third mission and the entrepreneurial university and the challenges they bring to higher education institutions. Journal of Enterprising Communities: People and Places in the Global Economy, 11(03), 354372. DOI: 10.1108/JEC-01-2017-0006

Siegel, D. S., Waldman, D. and Link, A., 2003a. Assessing the impact of organizational practices on the relative productivity of university technology transfer offices: An exploratory study. Research policy, 32(1), 27-48. DOI: 10.1016/S0048-7333(01)00196-2

Siegel, D. S., Westhead, P. and Wright, M., 2003b. Assessing the impact of university science parks on research productivity: Exploratory firm-level evidence from the United Kingdom. International Journal of industrial Organization, 21(9), 1357-1369. DOI: 10.1016/ S0167-7187(03)00086-9
Siegel, D.S., Waldman, D.A., Atwater, L. and Link, A.N., 2004. Toward a model of the effective transfer of scientific knowledge from academicians to practitioners: qualitative evidence from the commercialization of university technologies. Journal of Engineering and Technology Management, 21(1-2), 115-142.

Siegel, D. S., Veugelers, R. and Wright, M., 2007. Technology transfer offices and commercialization of university intellectual property: Performance and policy implications. Oxford Review of Economic Policy, 23(4), 640-660. DOI: 10.1093/oxrep/grm036.

Thursby, J.G., Jensen, R.A. and Thursby, M.C., 2001. Objectives, characteristics and outcomes of university licensing: a survey of major U.S. universities. Journal of Technology Transfer, 26(1-2), 59-70.

Tornatzky, L.G. and Waugaman, P.G., 1999. Academic Culture and Technology Transfer: Some Change Interventions. R\&D Enterprise Asia Pacific, 2(2-3), 29-30.

Tushman, M. L. and O'Reilly, C. A., 1996. Ambidextrous organizations: Managing evolutionary and revolutionary change. California Management Review, 38(4), 8-30. DOI: 10.2307/41165852

Van Looy, B., Landoni, P., Callaert, J., Van Pottelsberghe, B., Sapsalis, E. and Debackere, K., 2011. Entrepreneurial effectiveness of European universities: An empirical assessment of antecedents and trade-offs. Research Policy, 40 (4), 553-564. DOI: 10.1016/j. respol.2011.02.001

Vohora, A., Wright, M. and Lockett, A., 2004. Critical junctures in the development of university high-tech spinout companies. Research Policy, 55(1), 147-17. DOI: 10.1016/S0048-7333(03)00107-0

Wright, M., Clarysse, B., Lockett, A. and Knockaert, M., 2008. Midrange universities' linkages with industry: Knowledge types and role of intermediaries. Research Policy, 37(8), 1205-1223. DOI: 10.1016/j.respol.2008.04.021 